\title{
INFLUENCE OF THE SHOOTING DISTANCE ON THE DEPTH OF Penetration OF THE BUllet into THE REPLACEMENT MATERIAL FOR AIR GUN WEAPONS
}

\author{
Martin Ficek, Zdeněk Maláník, Michaela Mikuličová, \\ Michal Gracla
}
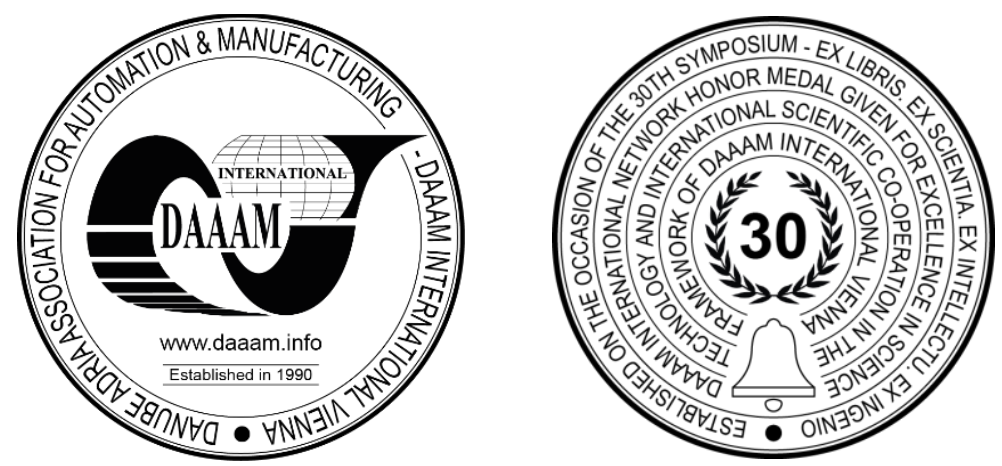

This Publication has to be referred as: Ficek, M[artin]; Malanik, Z[denek]; Mikulicova, M[ichaela] \& Gracla, M[ichal] (2019). Influence of the Shooting Distance on the Depth of Penetration of the Bullet into the Replacement Material for Air Gun Weapons, Proceedings of the 30th DAAAM International Symposium, pp.0663-0672, B. Katalinic (Ed.), Published by DAAAM International, ISBN 978-3-902734-22-8, ISSN 1726-9679, Vienna, Austria DOI: 10.2507/30th.daaam.proceedings.091

\begin{abstract}
In the last few years, it has been possible to see an increasing trend of aggression in society, leading to the more frequent use of weapons in conflicts. The using of air weapons is also increasing. But are these weapons really dangerous, and what is the effect of shooting distance on the depth of the shot? The article tries to answer these questions. The paper uses ballistic experiment to gain knowledge on which a qualitative evaluation is used. The shooting experiment is based on the firing of physical substitution models made of $20 \%$ ballistic gelatine from an air gun with a calibre of $4.5 \mathrm{~mm}$, at a distance of 5, 10, 15, 20 and $25 \mathrm{~m}$. The impact velocities of the projectile were measured using optical ballistic gates and using high-speed cameras were recorded missile passes ballistic gelatin. The depths of the shots were then measured using callipers, and the maximum dimensions and the shape of the temporary cavities of the shots were determined using optical recordings from the high-speed camera. It was found that the depth of the shot decreases with increasing shooting distance. The same applies to the maximum volumes of temporary cavities. These trends are almost linear and are associated with a drop in the impact velocity of the projectile hitting the test target. This pilot experiment serves for the initial verification of the hypothesis of the effect of shooting distance on the depth of shot in air gun weapons and provides essential information for further in-depth investigation.
\end{abstract}

Keywords: air rifle; ballistic gelatin; bullet; shot depth.

\section{Introduction}

Over the past few years, there has been an increase in aggression in society, and there have been instances of assaults using weapons. As evidenced by examples from the Czech Republic, USA, France and other countries, the number of cases where a weapon of lower efficiency such as an airsoft gun, a paintball gun, a Flobert gun or an air rifle appears. However, are these weapons really dangerous? Or what is the danger of shooting from $5 \mathrm{~m}$ and what is the danger of shooting from $20 \mathrm{~m}$ ? These questions are trying to answer wounded ballistics. This article and other articles that are produced in our research are focused on the impact of the shooting distance on the depth of the shot and, in a broader context, the wounding potential of the air rifle. 
This particular research may rely on publications such as:

Airsoft gun-related ocular injuries: long-term follow-up. [1] from Khalaila et al., where they examined eye injuries caused by airsoft guns. This publication was followed by an article by a group led by Kartik Dandu entitled A 10-Year Analysis of Head and Neck Injuries Involving Nonpowder Firearms. [2] The risks associated with airsoft guns is also discussed in the articles Traumatic iridoid analysis from an Airsoft pellet in an aviator by Pearce [3] and Penetrating Facial Injury with an "Airsoft" Pellet by Strong and Coady. [4]

Stefanopoulos et al., In Wound Ballistics 101: The Mechanisms of Soft Tissue Wounding by Bullets [5], focused on soft tissue injuries caused by bullets.

Interesting is also the publication Evolution of indoor bullet trap design by Tikal. [6] The use of ballistic gelatin is discussed in The Use of Gelatine in Wound Ballistics Research by Carr, Stevenson, and Mahoney. [7]

The publication Investigation and comparison of the performance of some air gun projectiles with nose shape modifications by Salimipour, Teymourtash and Mamourian [8] or Brain death of an infant caused by a penetrating air gun injury from a team led by Simon [9] deal directly with air guns. Interesting is also the Prediction of the Air Gun Performance by Horák et al. [10] and Air weapon fatalities from Milroy, Clark, Carter, Rutty and Rooney.[11]

The publications of prof. Juříček, such as the Czech-Slovak terminology dictionary of terms in the field of firearms, ammunition, wounded ballistics, pyrotechnics and forensic medicine [12], Wounded ballistics. Technical, forensic, and forensic aspects [13], The wounding potential of small-calibre projectiles and its evaluation [14], Physical models of human biological systems in a ballistic experiment to evaluate the wounding effects of a small-calibre missile [15], Simulation and evaluation of the impact of small-calibre projectiles on the live force.[16]

Interesting is also the article Detecting Differences At A Selected Shooting Weapon And Its Freely Available Copies by Gracla et al. [17]

The initial hypothesis is that the depth of shot and wounding potential will generally decrease with increasing shooting distance, and this trend could be linear.

This article deals with the effect of shooting distance on the depth of the shot of an air weapon.

\section{Methods}

To obtain the data, the experiment, which was to prove the underlying assumption that the depth of penetration of missiles into the test gelatin block (shot) and generally wounding potential decreases with increasing shooting distance, was conducted. Furthermore, it was assumed that the relationship between the shooting distance and the depth of penetration of the missile into the gelatin block could have a linear course.

The experiment consisted of a substitution test block made of $20 \%$ gelatin solution in the shape of a cuboid with dimensions of $15 \times 15 \times 30 \mathrm{~cm}$. Individual blocks were gradually shot from a distance of 5, 10, 15, 20 and $25 \mathrm{~m}$ with the recording of the impact velocity of the diabolo pellet vi using ballistic optical gates and capture the passage of missiles through the replacement material using a high-speed camera.

The following tools were used in the experiment:

- $20 \%$ ballistic gelatine was used as a replacement material, manufactured according to the procedure

- Crystalline gelatin was mixed into room temperature water with gentle stirring (to prevent bubble formation).

- The mixture was aged for 2 hours on a $10{ }^{\circ} \mathrm{C}$ in the fridge.

○ Subsequently, the gelatin container was placed in a bath of a larger water tank at $40{ }^{\circ} \mathrm{C}$, and the gelatin was dissolved entirely (without bubbles) while stirring and gradually heating.

- The gelatin was then poured into a preformed form (erased with silicone or transparent fat).

$\circ$ The gelatin was placed in the fridge at a temperature of approximately $10{ }^{\circ} \mathrm{C}$.

- After solidification and visual inspection, the gelatin was removed from the form and wrapped in polyethylene foil and placed in a $4{ }^{\circ} \mathrm{C}$ fridge to temper for 36 hours.

- The gelatin, used in the experiment, was at room temperature $(20 \mathrm{oC})$.

- The density of gelatin was $1,066 \mathrm{~kg} . \mathrm{m}-3$, which is very close to the density of human muscle (1,100 kg.m-3),

- Caldwell Matrix shooting stool with an air gun - Gamo Shadow DX calibre $4.5 \mathrm{~mm}$ with the type of ammunition used - Gamo Magnum Energy calibre $4.5 \mathrm{~mm}$ with conical face,

- Ballistic Optical Gates Shooting Chrony Beta Master with measuring range 9 - 2,100 m.s-1. They were built 10 $\mathrm{cm}$ from the ballistic gelatin.

- Olympus I-SPEED FS high-speed camera with a resolution of 1280 x 1,024, the maximum speed of 1,000,000 fps. A 10,000 fps scan rate was selected for the experiment,

- camera,

- Laser rangefinder and

- Digital calliper.

During the ballistic experiment, five rounds were fired from each distance. 


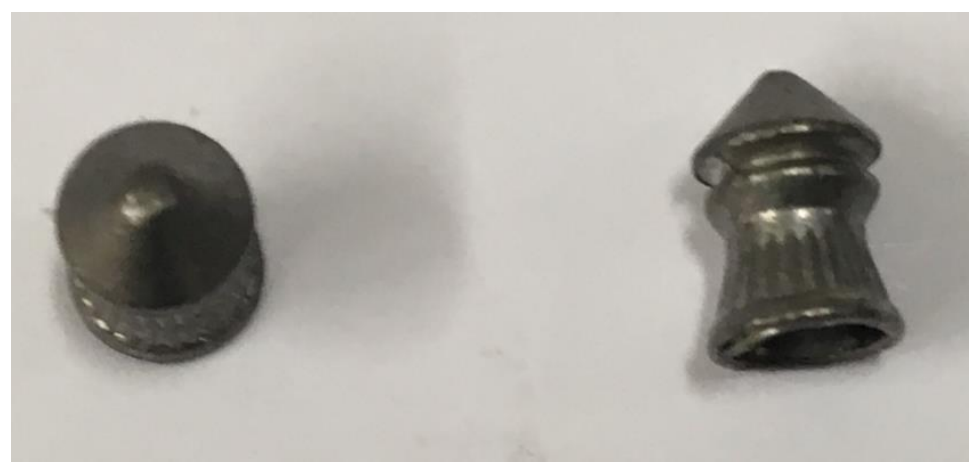

Fig. 1. Gamo Magnum Energy $4.5 \mathrm{~mm}$ calibre.

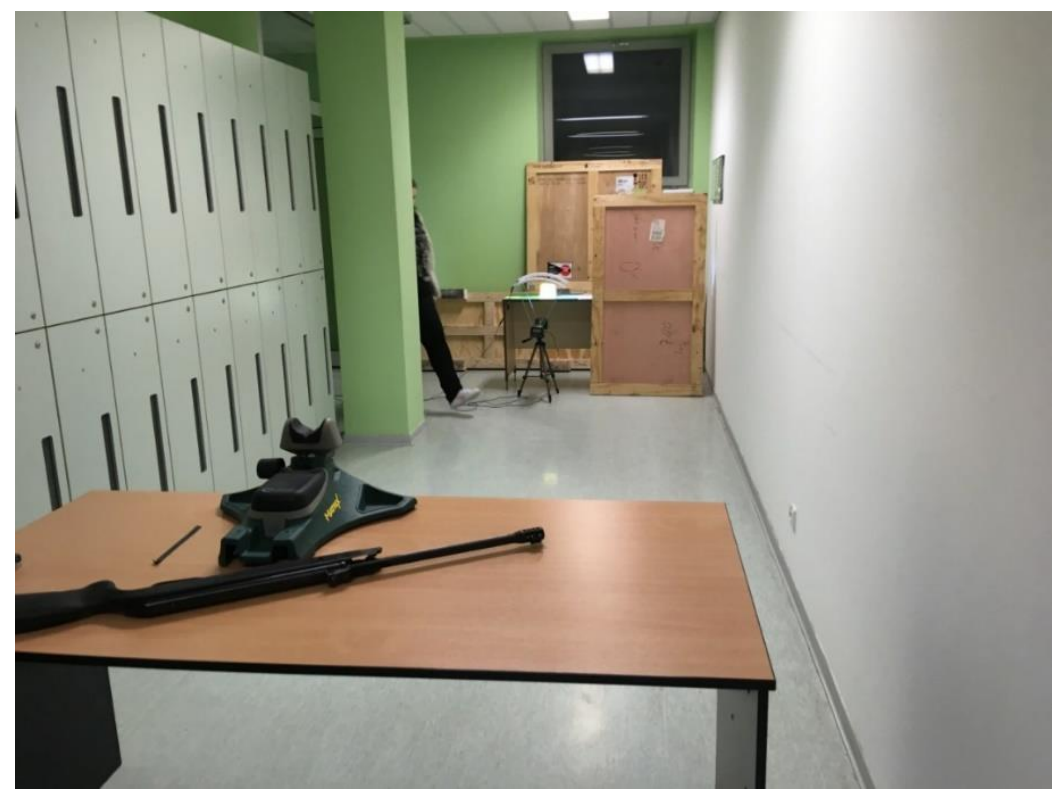

Fig. 2. Arrangement of the workplace 1.

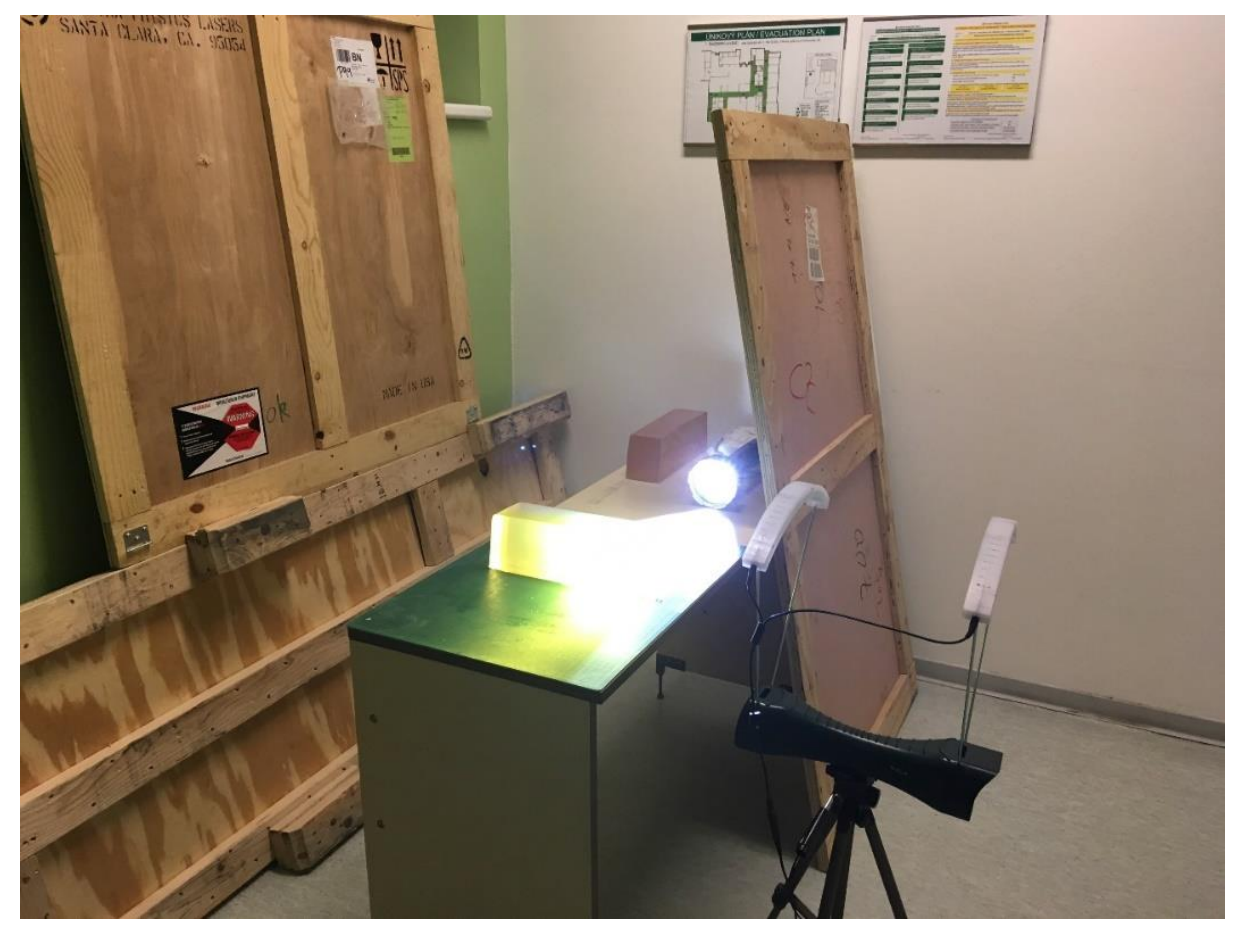

Fig. 3. Arrangement of the workplace 2. 


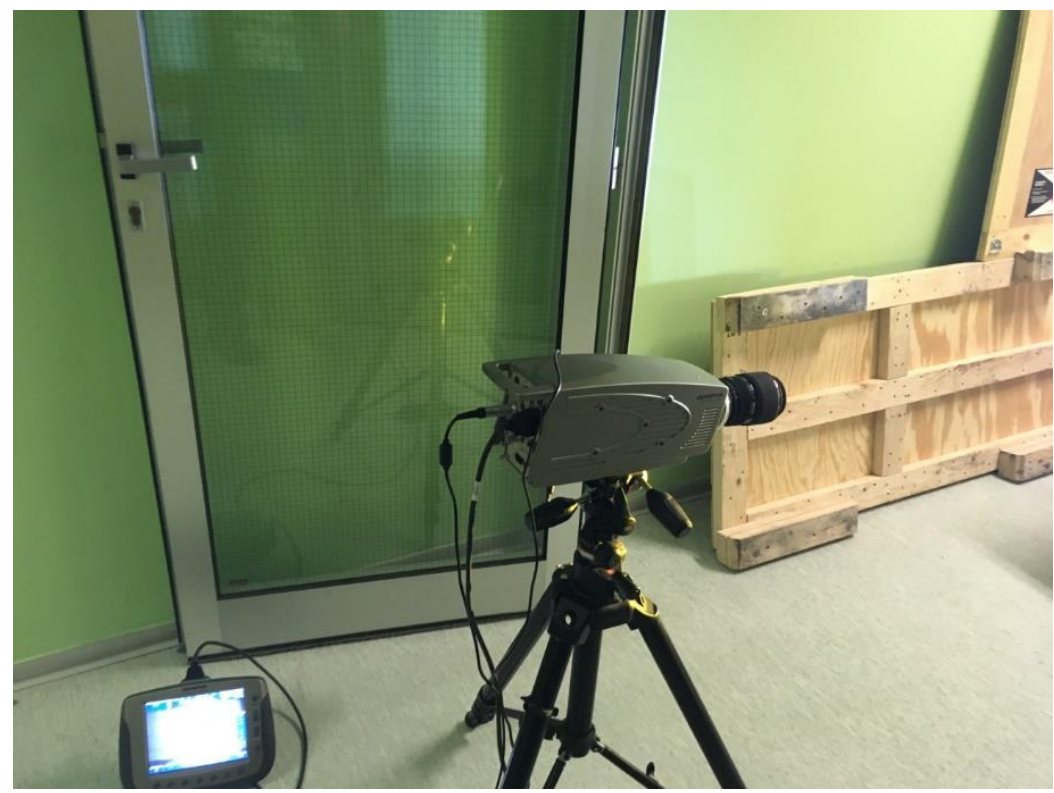

Fig. 4. Arrangement of the workplace 3.

\section{Results}

The following data were obtained from the experiment described above.

The impact velocity of missiles $v_{i}$

The impact velocity of the missiles was measured by ballistic gates. The gates were placed $10 \mathrm{~cm}$ in front of the replacement material block, and therefore, the measured velocity can be considered as the impact velocity.

\begin{tabular}{|l|c|c|c|c|c|}
\hline distance & $5 \mathrm{~m}$ & $10 \mathrm{~m}$ & $15 \mathrm{~m}$ & $20 \mathrm{~m}$ & $25 \mathrm{~m}$ \\
\hline \multicolumn{7}{|c|}{ Missile velocities $\mathrm{v}_{\mathrm{i}}$ at the moment of impact on the test block [m.s $\left.{ }^{-1}\right]$} \\
\hline 1. shot & 218 & 209 & 203 & 193 & 186 \\
\hline 2. shot & 220 & 211 & 204 & 195 & 187 \\
\hline 3. shot & 217 & 209 & 202 & 196 & 185 \\
\hline 4. shot & 215 & 204 & 199 & 191 & 183 \\
\hline 5. shot & 218 & 198 & 198 & 190 & 189 \\
\hline
\end{tabular}

Table 1. Impact velocities of missiles at $5 \mathrm{~m}, 10 \mathrm{~m}, 15 \mathrm{~m}, 20 \mathrm{~m}$ and $25 \mathrm{~m}$.

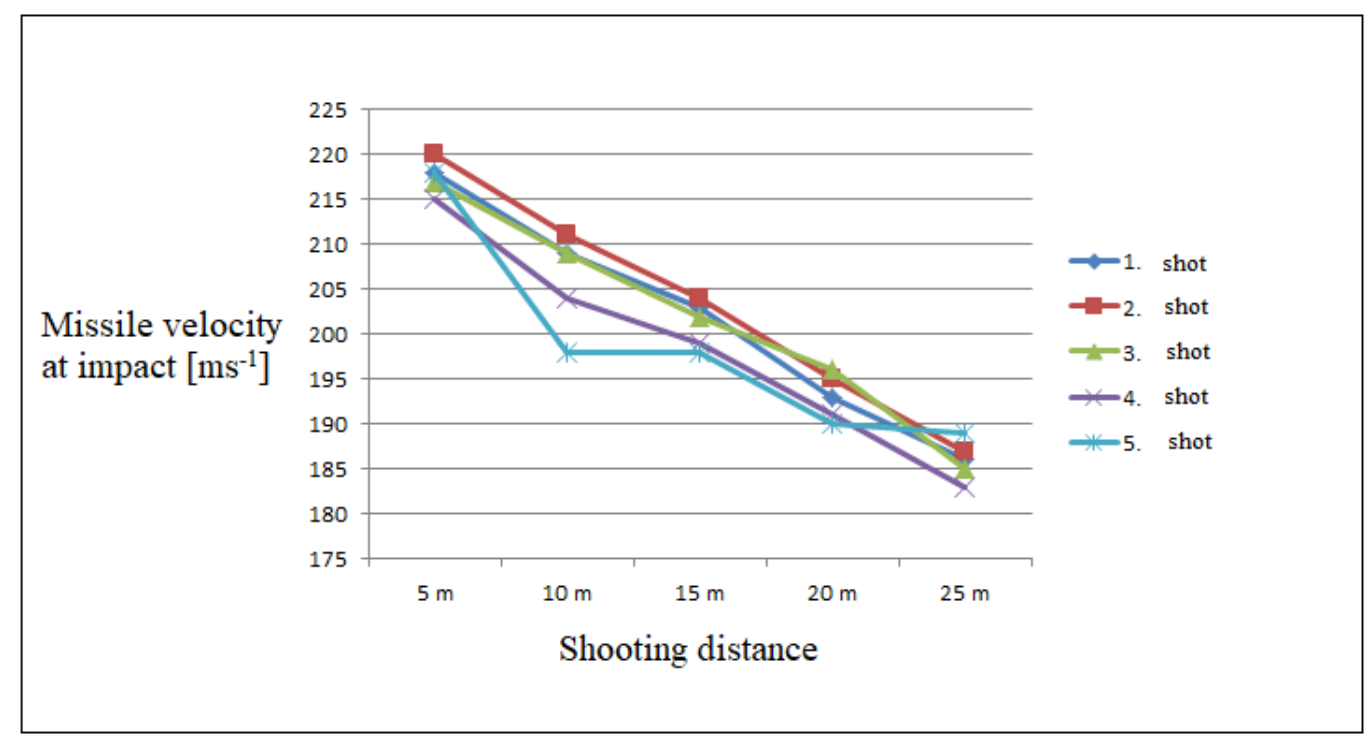

Graph 1. The development of the velocity of shots depending on the shooting distance. 
The graph and the table show that the velocity of missiles is not entirely proportional to the shooting distance. However, since the weight of each missile is slightly different, and it cannot be detected and guaranteed that each shot is fired with the same strength, it can be said that the relationship is almost linear.

Missile weight $\mathbf{m}_{\mathbf{q}}$

The weight of the bullets $\mathrm{m}_{\mathrm{q}}$ used for firing was gradually measured using a KERN PCB precision digital scale (1,000$2 ; 1,000 \mathrm{~g} / 0.01 \mathrm{~g}$ ). The measured missile weights are listed in Table 2 .

\begin{tabular}{|c|c|c|c|c|c|}
\hline distance & $5 \mathrm{~m}$ & $10 \mathrm{~m}$ & $15 \mathrm{~m}$ & $20 \mathrm{~m}$ & $25 \mathrm{~m}$ \\
\hline \multicolumn{6}{|c|}{ Missile weight $[\mathrm{g}]$} \\
\hline 1. shot & 0,486 & 0,486 & 0,487 & 0,493 & 0,489 \\
\hline 2. $\quad$ shot & 0,497 & 0,485 & 0,489 & 0,492 & 0,499 \\
\hline 3. $\quad$ shot & 0,486 & 0,484 & 0,489 & 0,485 & 0,497 \\
\hline 4. shot & 0,481 & 0,484 & 0,485 & 0,489 & 0,493 \\
\hline 5. shot & 0,489 & 0,488 & 0,481 & 0,498 & 0,489 \\
\hline
\end{tabular}

Table 2. Weights of missiles mq fired at a certain distance.

\section{Impact kinetic energy $E_{i}$ of a missile}

Using the data in Tables 4 and 5, the kinetic energy of the incident missile $E_{\mathrm{i}}$ can be determined. Since the bullet has completely stopped in the replacement material block and the shot has been recorded, the impact kinetic energy value of the bullet represents its total kinetic energy transmitted $\mathrm{E}_{\mathrm{TR}}$.

Calculation of the kinetic energy of the projectile can be done according to Newton's mechanics as:

$$
E_{k}=\frac{1}{2} m v^{2}
$$

where $E_{T R}[J]$ is kinetic energy, $m_{q}$ is the weight of the bullet and $v_{i}$ is the velocity of the incident bullet.

After the values of the velocities and weights of the missiles corresponding to the individual shooting distances have been achieved, the values of the transmitted kinetic energy $\mathrm{E}_{\mathrm{TR}}$ of the bullet to the replacement material can be calculated.

\begin{tabular}{|c|c|c|c|c|c|}
\hline distance & $5 \mathrm{~m}$ & $10 \mathrm{~m}$ & $15 \mathrm{~m}$ & $20 \mathrm{~m}$ & $25 \mathrm{~m}$ \\
\hline \multicolumn{6}{|c|}{ Transmitted kinetic energy of the projectile [J] } \\
\hline 1. $\quad$ shot & 11,548 & 10,614 & 10,034 & 9,182 & 8,459 \\
\hline 2. $\quad$ shot & 12,027 & 10,796 & 10,175 & 9,354 & 8,725 \\
\hline 3. $\quad$ shot & 11,443 & 10,471 & 9,977 & 9,316 & 8,505 \\
\hline 4. $\quad$ shot & 11,117 & 10,071 & 9,603 & 8,920 & 8,255 \\
\hline 5. $\quad$ shot & 11,620 & 9,566 & 9,429 & 8,989 & 8,734 \\
\hline
\end{tabular}

Table 3. Transmitted kinetic energy of missiles fired at a certain distance.

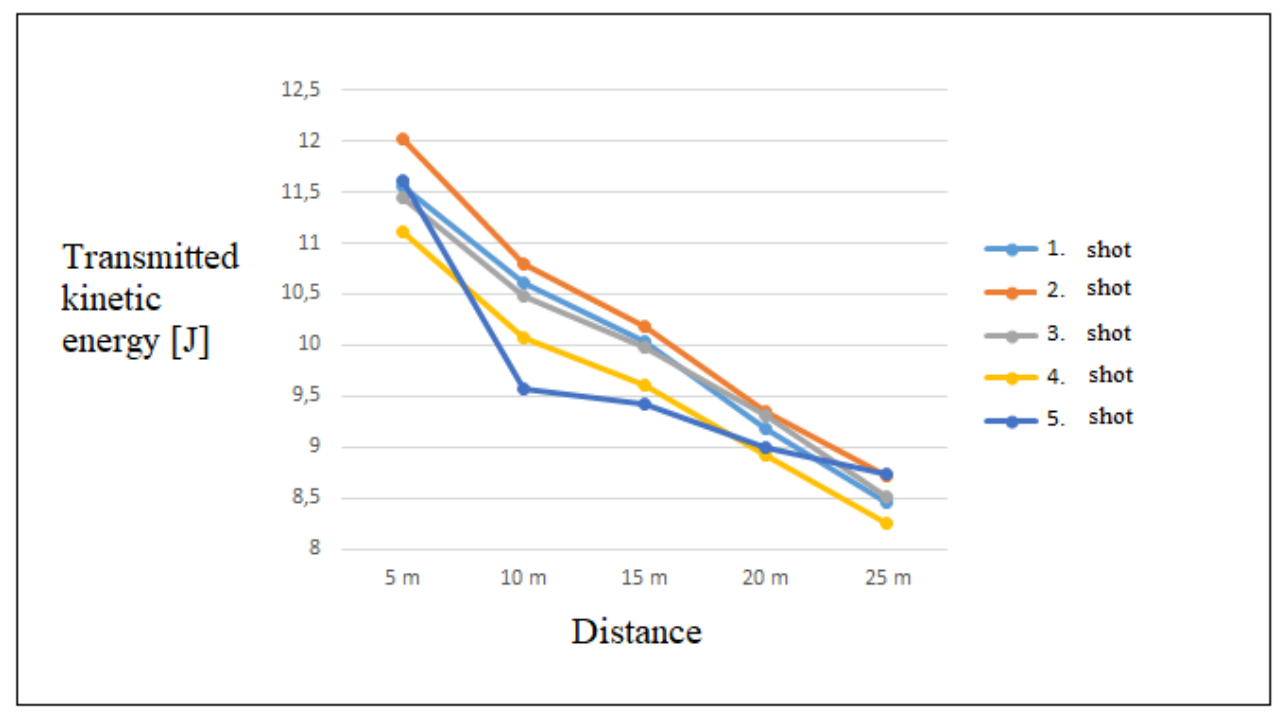

Graph 2. Transmitted kinetic energy. 
The graph and table show that the transmitted kinetic energy decreases with the shooting distance. It is difficult to determine the trend of descent because each bullet has a different weight and rate of fire. If extremes are excluded and differences are taken into account, the drop is similar to direct proportion.

\section{Depth of penetration of a missile $s$}

Shot depth was measured using a digital calliper.

\begin{tabular}{|c|c|c|c|c|c|}
\hline distance & $5 \mathrm{~m}$ & $10 \mathrm{~m}$ & $15 \mathrm{~m}$ & $20 \mathrm{~m}$ & $25 \mathrm{~m}$ \\
\hline \multicolumn{6}{|c|}{ Depth of penetration missiles s [mm] } \\
\hline 1. shot & 74 & 69 & 66 & 60 & 55 \\
\hline 2. $\quad$ shot & 75 & 70 & 68 & 62 & 57 \\
\hline 3. $\quad$ shot & 72 & 68 & 66 & 61 & 56 \\
\hline 4. shot & 70 & 68 & 64 & 60 & 56 \\
\hline 5. shot & 69 & 67 & 65 & 61 & 59 \\
\hline
\end{tabular}

Table 4. Values of penetration depths of missiles fired from a certain distance.

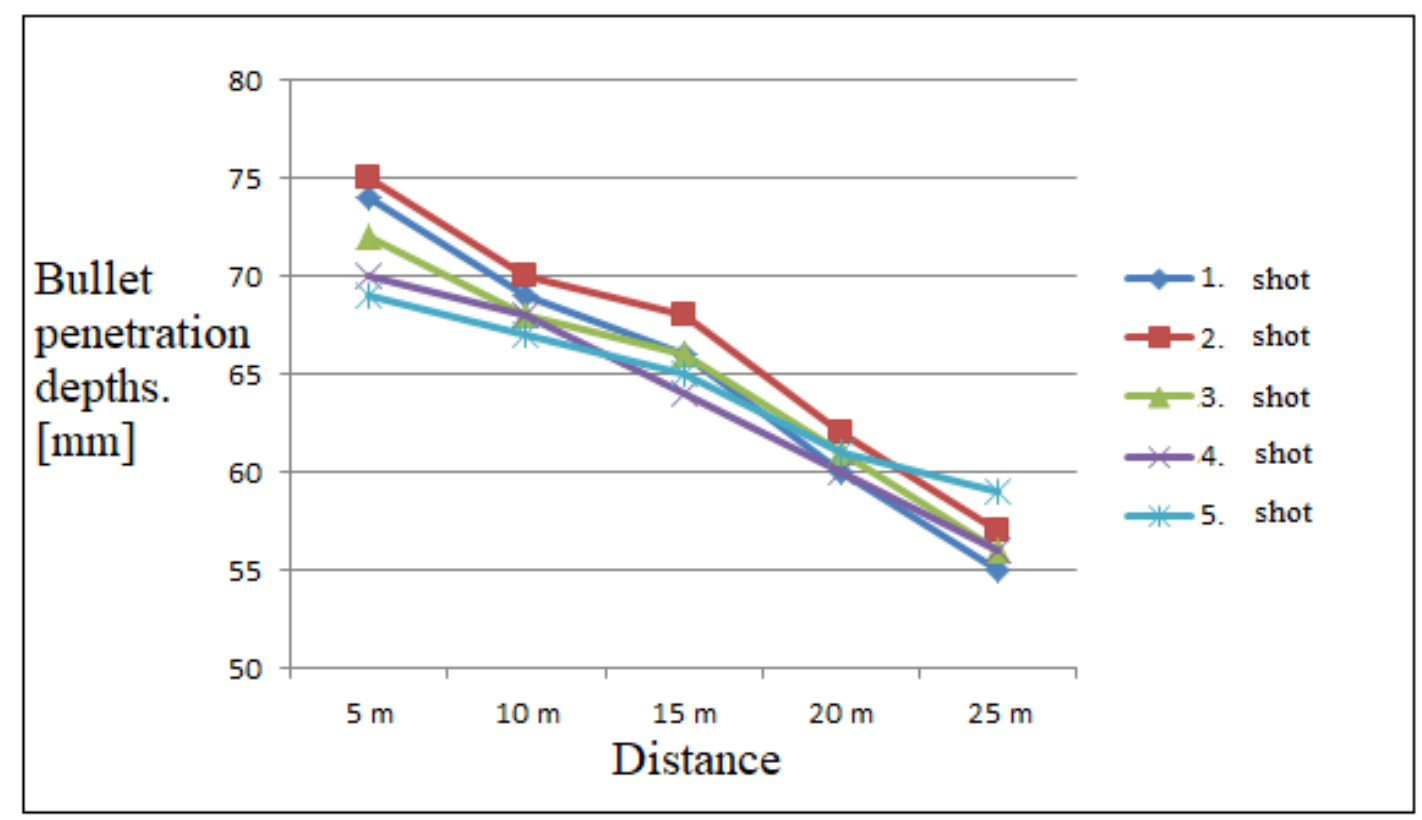

Graph 3. Bullet penetration depths.

As can be seen from Graph 3 and Table 7, the depth of penetration of individual missiles is not entirely proportional to the shooting distance. However, since the weight of each missile is slightly different and within a certain tolerance, and it is not possible to ensure that the projectile is fired from the air rifle with the same strength each time, it can be stated that the proportionality is linear with a certain dose of tolerance.

\section{Temporary cavity dimension wTC}

The dimension of the temporary cavity, represented by its maximum width wTC, was measured using an optical method. Specifically, high-speed camera recordings were analysed. Unfortunately, at the time of the experiment and preparation of this article, specialized software for image analysis was not available, and therefore, the method of pixel measurement was used.

An object of known size is identified in the image. Then, the number of pixels is determined, and the size of the object is divided by the number of pixels. This determines the size of one pixel. The number of pixels at the desired length of the temporary cavity is then determined and multiplied by the size of one pixel. The dimension of the temporary cavity is thereby obtained.

For the sake of clarity, images are shown only for the first missiles at given distances and only the maximum dimension of the temporary cavity represented by its maximum width is measured. Images are cropped to show only temporary cavity and missile. The dimensions of all temporary cavities are given in Table 5 and then converted to Graph 4 . 


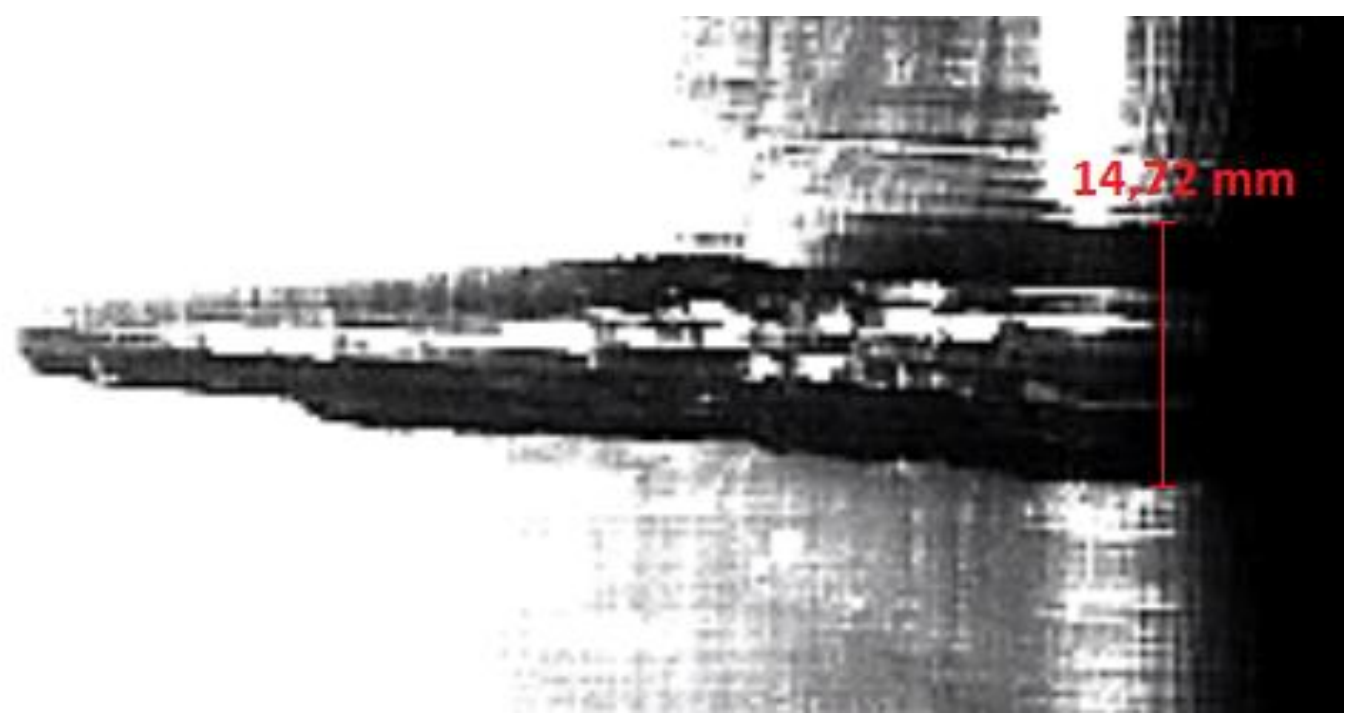

Fig. 5. The dimension of the maximum width of the temporary cavity for the first missile at a distance of $5 \mathrm{~m}$.

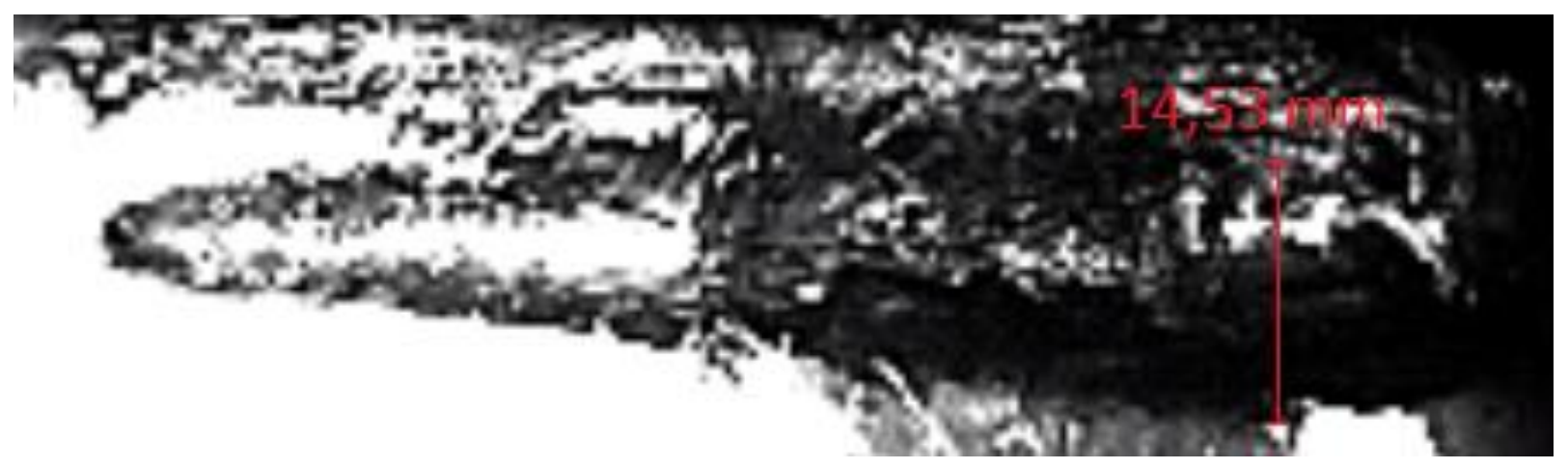

Fig. 6. The dimension of the maximum width of the temporary cavity for the second missile at a distance of $10 \mathrm{~m}$.

Figure 8 shows the second bullet fired from a distance of $10 \mathrm{~m}$ due to unreadable record of the first missile. The second bullet penetrated near the first bullet, and so it can be seen that the temporary cavity of the second bullet pulsation acts on the permanent cavity of the first bullet, which can be significantly affected. The temporary cavity of the second bullet thus creates another temporary cavity even in the cavity formed by the first bullet.

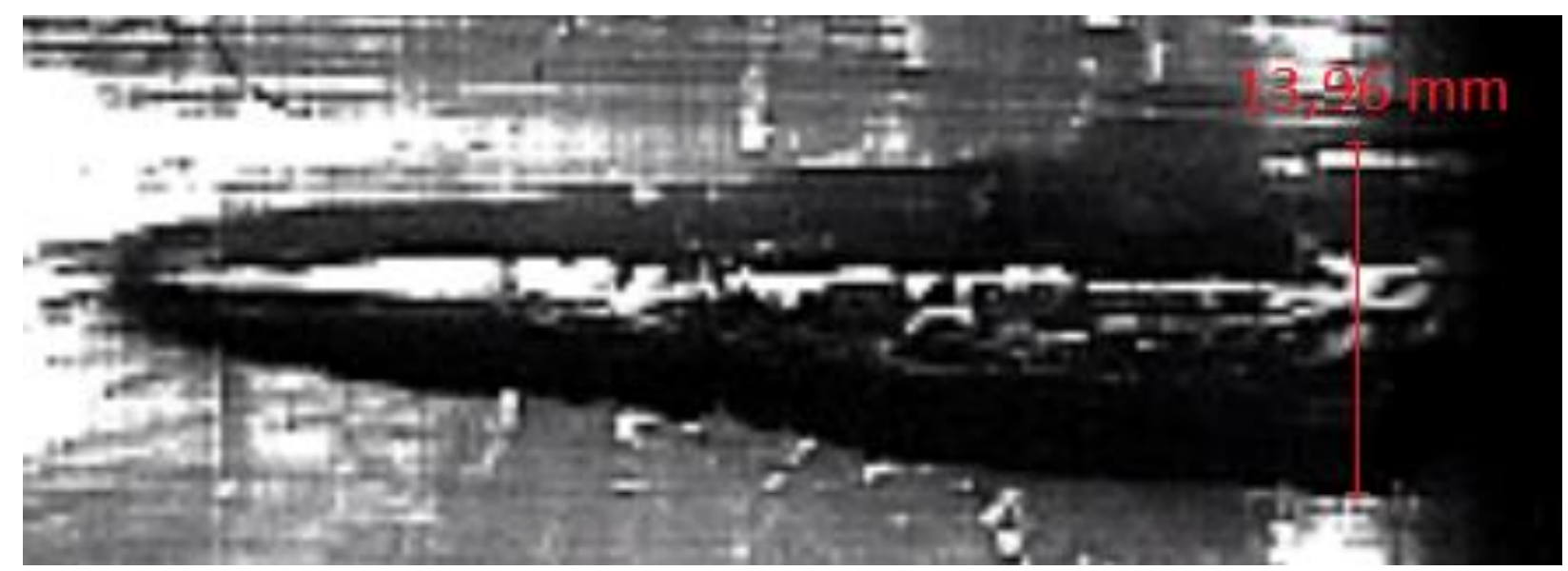

Fig. 7. The dimension of the maximum width of the temporary cavity for the first missile at a distance of $15 \mathrm{~m}$. 


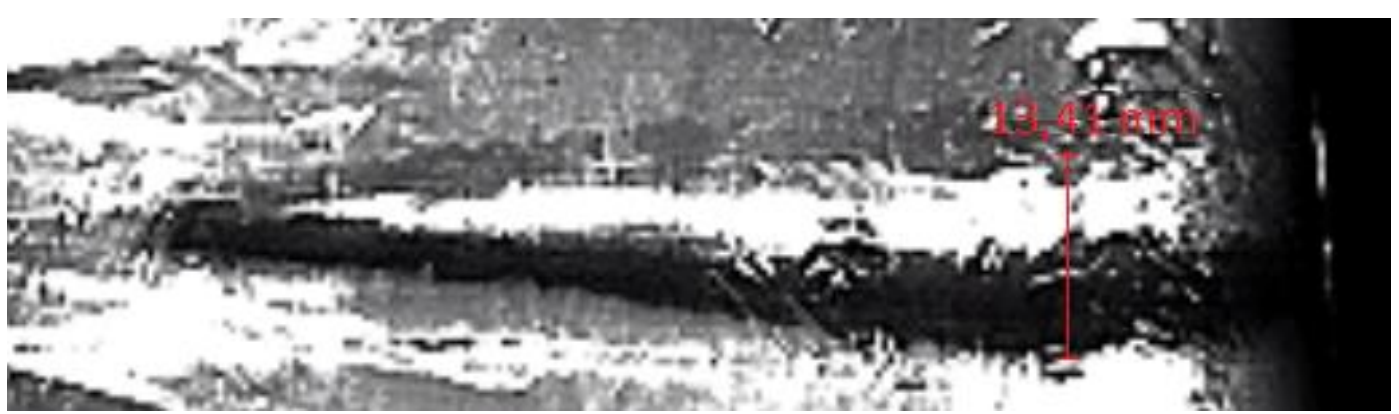

Fig. 8. The dimension of the maximum width of the temporary cavity for the first missile at a distance of $20 \mathrm{~m}$.

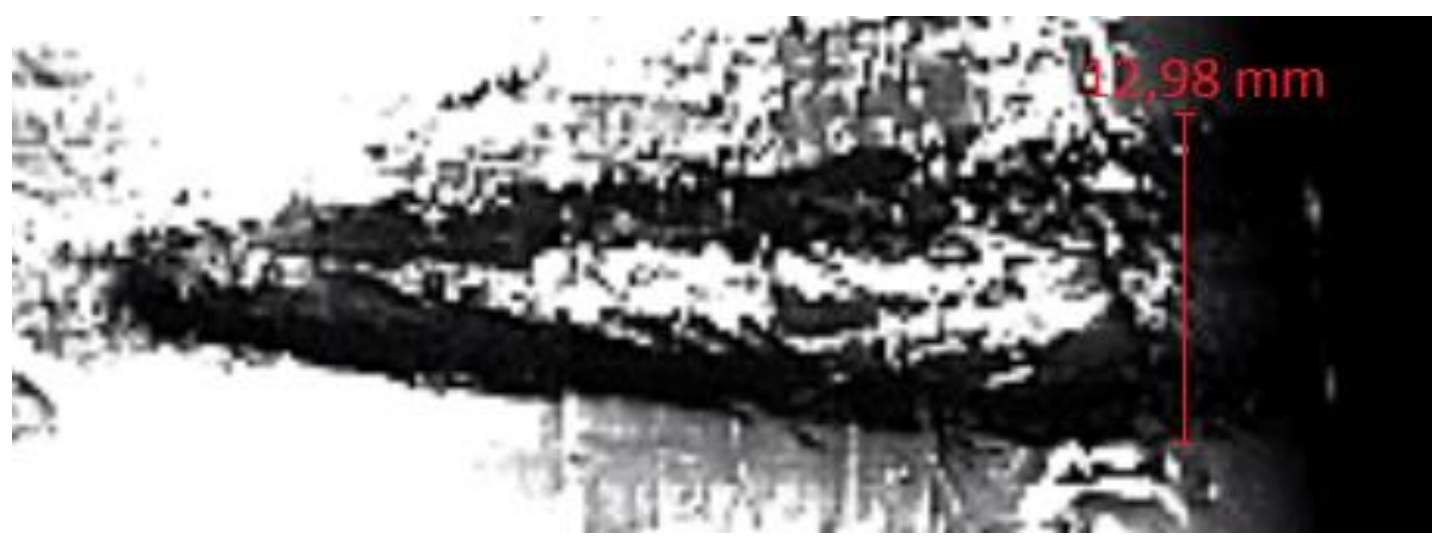

Fig. 9. The dimension of the maximum width of the temporary cavity for the first missile at a distance of $25 \mathrm{~m}$.

\begin{tabular}{|c|c|c|c|c|c|}
\hline distance & $5 \mathrm{~m}$ & $10 \mathrm{~m}$ & $15 \mathrm{~m}$ & $20 \mathrm{~m}$ & $25 \mathrm{~m}$ \\
\hline \multicolumn{6}{|c|}{ Maximum temporary cavity width values wTC [mm] } \\
\hline 1. shot & 14,72 & 14,53 & 13,96 & 13,41 & 12,98 \\
\hline 2. shot & 14,81 & 14,59 & 14,03 & 13,43 & 13,00 \\
\hline 3. shot & 14,69 & 14,43 & 13,90 & 13,36 & 12,89 \\
\hline 4. shot & 15,02 & 14,71 & 14,12 & 13,40 & 12,96 \\
\hline 5. shot & 14,70 & 14,51 & 13,94 & 13,39 & 12,87 \\
\hline
\end{tabular}

Table 5. The maximum width of the temporary cavity for the missiles fired at a certain distance.

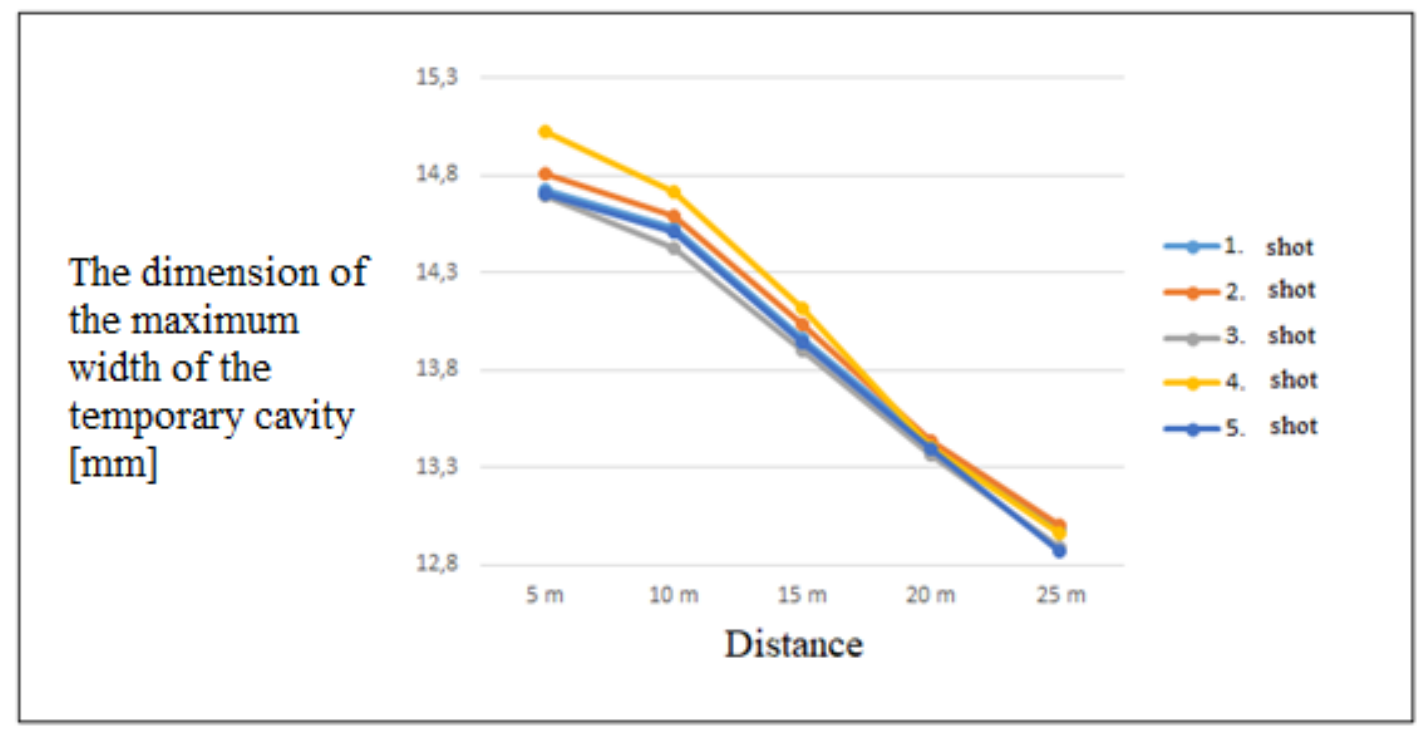

Graph 4 . The dimension of the maximum width of the temporary cavity [mm]. 
Interestingly, the descent trend in the first 5 meters is different from the rest of the measurement. Besides, the descent is almost linear and confirms trends in missile velocity and transmitted kinetic energy.

\section{Conclusion}

This article deals with the effect of shooting distance on the depth of the shot of an air weapon. From the above findings, it can be stated that the original assumption has been confirmed and that the wounding potential depending on the shooting distance decreases linearly. The results of experimental ballistic measurements confirmed this hypothesis. It should be noted that more detailed experimental ballistic measurements may result in some differences. The weight of the "Diabolo" missiles ranged from $0.481 \mathrm{~g}$ to $0.499 \mathrm{~g}$. Impact velocities vi and transmitted kinetic energy $\mathrm{E}_{\mathrm{TR}}$ when shooting from a distance of $5 \mathrm{~m}$ ranged between $215-220 \mathrm{~ms}^{-1}$ and $11.117-12.027 \mathrm{~J}$, per $10 \mathrm{~m}$ : $198-211 \mathrm{~ms}^{-1}$ and $9.566-10.796 \mathrm{~J}$, at $15 \mathrm{~m}: 198-204 \mathrm{~ms}^{-1}$ and $9.429-10.175 \mathrm{~J}$, at $20 \mathrm{~m}: 190-196 \mathrm{~ms}^{-1}$ and $8.920-9.354 \mathrm{~J}$ and at $25 \mathrm{~m}: 183-189 \mathrm{~ms}^{-1}$ and 8.255 - 8.734 J. Maximum temporary cavity width per $5 \mathrm{~m}: 14.69$ - $15.02 \mathrm{~mm}, 10 \mathrm{~m} 14.43$ - $14.71 \mathrm{~mm}, 15 \mathrm{~m} 13.90$ $14.12 \mathrm{~mm}$, for $20 \mathrm{~m} 13.36-13.43 \mathrm{~mm}$ and for $25 \mathrm{~m} 12.87-13.00 \mathrm{~mm}$.

The maximum temporal cavity dimension data are crucial for assessing the missile potential of the projectile. It is always located near the bullet entry into the replacement material block. Moreover, the maximum dimension for given distances shows that the wounding potential is not negligible, but is relatively small. Nevertheless, it is necessary to objectify further this area. The results of this article provide a solid basis for further research in the field that the authors are planning to perform.

\section{Acknowledgments}

This work was supported by the Internal Grant Agency of Tomas Bata University under the project No. IGA/FAI/2019/003.

\section{References}

[1] Khalaily, Soltan et al. (2018). Airsoft gun-related ocular injuries: long-term follow-up, Journal of American Association for Pediatric Ophthalmology and Strabismus. 22(2), 107-109, ISSN 10918531, DOI: 10.1016/j.jaapos.2017.10.019. WWW: https://linkinghub.elsevier.com/retrieve/pii/S1091853116305407

[2] Dandu, Kartik V. et al. (2017). A 10-Year Analysis of Head and Neck Injuries Involving Nonpowder Firearms, Otolaryngology-Head and Neck Surgery. 156(5), 853-856.. ISSN 0194-5998. DOI: 10.1177/0194599817695546 WWW: http://journals.sagepub.com/doi/10.1177/0194599817695546

[3] Pearce, S.M. (2012). Traumatic iridoid analysis from an Airsoft pellet in an aviator. Consultant. 2012(12), 807-808. ISSN 00107069.

[4] Strong, B and Martin Coady, (2014). Penetrating Facial Injury with an "Airsoft" Pellet: A Case Report. British Journal of Oral and Maxillofacial Surgery. 52(9), e129-e131. ISSN 02664356 DOI: 10.1016/j.bjoms.2014.05.007. WWW: https://linkinghub.elsevier.com/retrieve/pii/S0266435614002113

[5] Stefanopoulos, P. K. et al., (2017). Wound ballistics 101: the mechanisms of soft tissue wounding by bullets. European Journal of Trauma and Emergency Surgery [online]., vol. 43, no. 5, s. 579-586 WWW: https://www.scopus.com/inward/record.uri?eid=2-s2.0-84944612322\&doi=10.1007\%2fs00068-015-05811\&partnerID=40\&md5=81d3f4350ba2cc4d391cb0895a9bae0b.

[6] Tikal, F. (2015). Evolution of indoor bullet trap design [online]. 26th DAAAM International Symposium on Intelligent Manufacturing and Automation. 385-390 s. WWW: https://www.scopus.com/inward/record.uri?eid=2s2.0-

84987668179\&doi=10.2507\%2f26th.daaam.proceedings.052\&partnerID=40\&md5=d3541d427996d86d5a5daa67 $10 \mathrm{cdc} 025$

[7] Carr, D. J., T. Stevenson, and P. F. Mahoney. (2018). The use of Gelatine in Wound Ballistics Research. International Journal of Legal Medicine: 1-6. doi:10.1007/s00414-018-1831-7. WWW: https://www.scopus.com/inward/record.uri?eid=2-s2.0-85046414181\&doi=10.1007\%2fs00414-018-18317\&partnerID=40\&md5=0f19ce6504f6a8d89aa68c6985db5390.

[8] Salimipour, S. E., A. R. Teymourtash and M. Mamourian. (2019) Investigation and comparison of performance of some air gun projectiles with nose shape modifications. Proceedings of the Institution of Mechanical Engineers, Part P: Journal of Sports Engineering and Technology [online]. vol. 233, no. 1, s. 3-15 WWW: https://www.scopus.com/inward/record.uri?eid=2-s2.0-

85060252861\&doi=10.1177\%2f1754337118759159\&partnerID=40\&md5=98dd1845a9c3c7249cf7d3ac3b859b5.

[9] Simon, G. et al. (2019) Brain death of an infant caused by a penetrating air gun injury. Legal Medicine [online]. 2019, vol. 39, s. 41-44. WWW: https://www.scopus.com/inward/record.uri?eid=2-s2.085067178540\&doi=10.1016\%2fj.legalmed.2019.06.004\&partnerID=40\&md5=446d6455de4961884b445cfc3f48d ed8.

[10] Horák, V. et al. (2014). Prediction of air gun performance. Advances in Military Technology. 9(1), 31-44. ISSN 18022308 . 
[11] C. M. Milroy, J. C. Clark, N. Carter, G. Rutty, and N. Rooney. (2014). Air weapon fatalities, Journal of Clinical pathology, pp. 525-529

[12] Juříček, Ludvík et al. (2019) Czech-Slovak Terminology Dictionary of Firearms, Ammunition, Morning Ballistics, Pyrotechnics and Forensic Medicine (Česko-slovenský terminologický slovník pojmů z oblasti střelných zbraní, munice, ranivé balistiky, pyrotechniky a soudního lékařství). 279 s. ISBN 978-80-8054-800-1, EAN 9788080548001.

[13] Juříček, Ludvík et al. (2017). Wounding Ballistic. Technical and forensic aspects (Ranivá balistika. Technické, soudnělékařské a kriminalistické aspekty), 614 p. ISBN 978-80-7418-274-7.

[14] Juříček, Ludvík. (2015) The wounding potential of small-calibre projectiles and its evaluation (Ranivý potenciál malorážových střel a jeho hodnocení). 158 p. ISBN 978-80-7418-222-8.

[15] Juříček, Ludvík. (2003) Physical models of human biological systems in the ballistic experiment for evaluation of wounding effects of small-calibre missiles (Fyzikální modely biologických systémů člověka $\mathrm{v}$ balistickém experimentu pro hodnocení ranivých účinků malorážových střel.) 182 p.

[16] Juříček, Ludvík. (2000) Simulation and evaluation of effects of small-calibre projectiles on the life force (Simulace a hodnocení účinků malorážových střel na živou sílu.), 132 p.

[17] Gracla, Michal, Michaela Mikulicova, and Zdenek Malanik. (2018). Detecting Differences At A Selected Shooting Weapon And Its Freely Available Copies. Proceedings Of The 29Th International Daaam Symposium 2018, DAAAM Proceedings, December. DAAAM International Vienna, 1139-1143. doi:10.2507/29th.daaam.proceedings.163. 